\title{
The Determinants of Corporate Hedging Policy: A Case Study from Indonesia
}

\author{
Submitted 31/01/19, 1st revision 7/2/19, accepted 15/2/19
Sugeng Wahyudi ${ }^{1}$, Fernando Goklas ${ }^{2}$, Maria Rio Rita ${ }^{31^{*}}$, Hersugondo Hersugondo ${ }^{4}$, Rio Dhani Laksana ${ }^{5}$

\begin{abstract}
:
Looking at general, the company will hedge when the amount of foreign debt rises along with fluctuations in foreign exchange rates.

However, this is not the case with the non-financial sector companies in Indonesia Stock Exchange, which shows a decrease in the use of derivative instruments compared to financial sector companies during the period 2014-2016.

The study aims to analyze the effect of internal factors on hedging policies through the use of derivative instruments in nonfinancial companies in the period 2014-2016, by putting the firm size as a control variable. The logistic regression analysis is used to test the antecedents of the hedging policy from the selected sample.

The result shows that the liquidity and cash flow volatility have a significant positive effect on the use of derivative instruments. Meanwhile, dividend payout ratio, managerial ownership, leverage and the growth opportunity have no significant effect on hedging policy.
\end{abstract}

Keywords: Hedging, derivative instruments, liquidity, volatility of cash flow, company size.

JEL Code: G23, G32.

\footnotetext{
${ }^{1}$ Diponegoro University, Indonesia, sug_w@yahoo.com

${ }^{2}$ Diponegoro University, Indonesia, fgoklas10@ gmail.com

${ }^{3}$ Diponegoro University, and Satya Wacana Christian University, Indonesia, maria.rita@uksw.edu;

${ }^{4}$ Diponegoro University, Indonesia, gondoarum65@gmail.com

${ }^{5}$ Jenderal Soedirman University, Indonesia, riodhani@unsoed.ac.id

$1 *$ Corresponding author
} 


\section{Introduction}

Hedging in the financial term can be interpreted as an investment method to reduce or eliminate the risk in another investment activity (Stulz, 2013). The principle of hedging itself is to cover the loss of the initial asset position with the advantage of the hedging instrument position. Massa and Simonov (2006) argued that hedging is a tool to manage risk, in which investors hold financial assets at risk to offset the risks of their non-financial income.

One of the most commonly used ways of implementing hedging policies is by using an instrument derivative (Cusatis \& Thomas, 2005). The types of assets that can serve as underlying assets can vary greatly, ranging from securities such as stocks and bonds (Avellaneda, Levy, \& Parás, 1995; Laksana, Hersugondo, Wahyudi, \& Muharam, 2017; Merton, 1976), commodities (Figlewski, 1984; Georgiev, 2001; Junkus \& Lee, 1985; Schwartz, 1997), forex (Allayannis \& Ofek, 2001; Garman \& Kohlhagen, 1983; Glen \& Jorion, 1993) and other derivative instruments. However, in order to minimize the risk of foreign exchange fluctuations, hedging policies are conducted through foreign exchange derivative instruments such as forward contracts, futures contracts, currency options and currency swaps (Eun \& Resnick, 1988; Feiger \& Jacquillat, 1979; Hill \& Schneeweis, 1981).

A manager can use financial policies to communicate with the external investors (Laksana \& Hersugondo, 2016; Palepu, Healy, \& Bernard, 2004). In addition to that, the implementation of hedging policy is considered more valuable because it can show the internal activities that can increase the value of the company. The hedging strategies itself with derivative instruments are performed to optimize the risk management processes in the company (Graham \& Rogers, 1999). The internal and external factors in firms have an effect in the implementation of hedging policies (Allayannis, Lel, \& Miller, 2012). The external factors that can affect hedging policy are exchange rate fluctuations and total foreign debt owned by the company.

Figure 1. The movement of rupiah's exchange rate to us dollar, 2010-2014

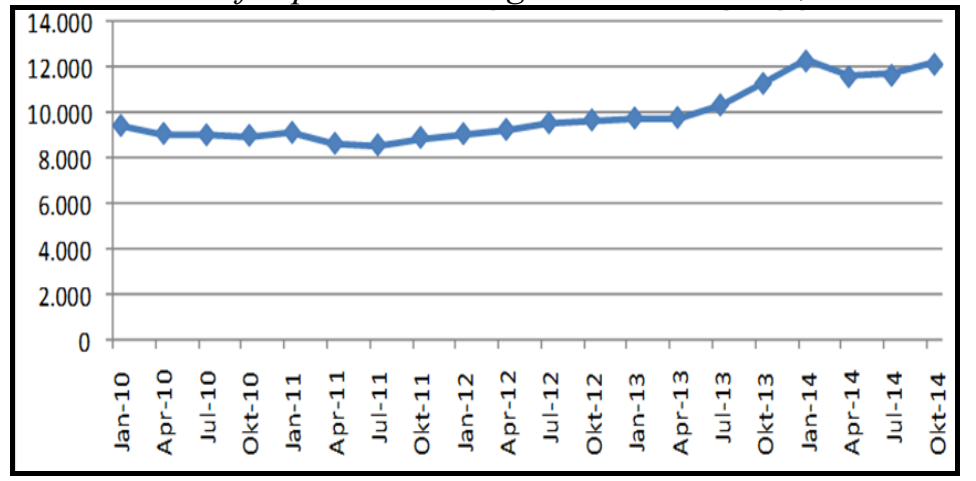

Source: Own elaboration, with data from www.idx.co.id (2018). 
Figure 1 shows the fluctuations in the rupiah's exchange rate against the dollar per quarter of 2010-2014. During the annual period of January 2010 to January 2011, rupiah tended to strengthen against the US dollar, but since April 2011 - January 2014 , it tended to weaken against the US dollar exchange rate. The peak of its weakening against the dollar was in the period of January 2014 which reached more than IDR.12.000 per dollar. The changes in exchange rates cause firms to face some exposure, such as transaction exposure (Martin \& Mauer, 2003), accounting exposure (Aggarwal, 1991), operating exposure (Pantzalis, Simkins, \& Laux, 2001).

Figure 2. The curve on the foreign debt from non-financial companies by "the borrowing group" (in million dollars), 2010-2014

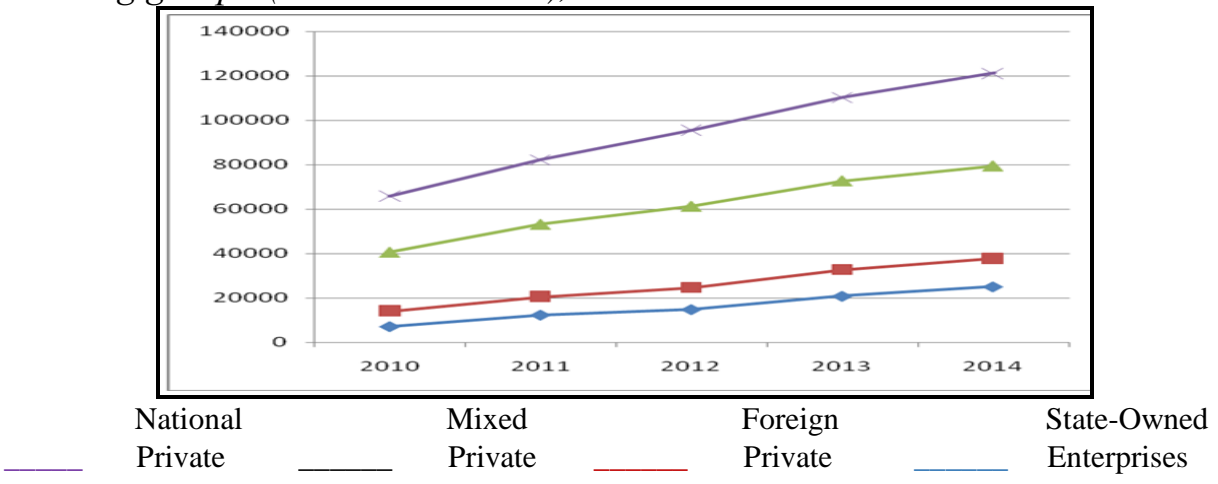

Source: Own elaboration, with data from www.idx.co.id (2018).

Figure 2 shows the movement of foreign debt from non-financial sector companies in Indonesia to foreigners from 2010 to 2014. There are four categories of nonfinancial companies that lend to foreign parties, namely national private, mixed private, foreign private and state-owned enterprises known as "Badan Usaha Milik Negara". It is known that the level of debt in non-financial companies in Indonesia tended to increase from 2010-2014. This indicates that non-financial corporations in Indonesia routinely and intensively seek additional funding for their companies to support their operational and investment activities. Increasing the amount of nonfinancial corporate debt each year will increase the risk that may be faced by the company. One of the risks is the liquidity that keeps the company from issuing its cash reserves to repay the debt, leaving the company illiquid. A much worse risk is when the higher level of debt is accompanied by an increase in the exchange rate of the fund provider. As a result, the amount of expenses to be paid will increase. Therefore, the level of foreign debt can be used as a reference by the company to conduct hedging policy or not.

However, it turns out that until 2014 the number of companies conducting hedging policies with derivative instruments is still quite small, see the Table 1. 
Table 1. The number of financial and non-financial companies which did not hedge with derivative instruments in indonesia stock exchange, 2010-2014

\begin{tabular}{ccccc}
\hline \multirow{2}{*}{ Year } & \multicolumn{2}{c}{ Financial Companies } & \multicolumn{2}{c}{ Non-Financial Companies } \\
\cline { 2 - 5 } & Total & Percentage & Total & Percentage \\
\hline 2010 & 48 & $60 \%$ & 273 & $79.59 \%$ \\
\hline 2011 & 47 & $61,04 \%$ & 293 & $80.05 \%$ \\
\hline 2012 & 49 & $59,76 \%$ & 311 & $80.57 \%$ \\
\hline 2013 & 44 & $54,33 \%$ & 332 & $80.78 \%$ \\
\hline 2014 & 41 & $51,25 \%$ & 348 & $81.30 \%$ \\
\hline
\end{tabular}

Source: Own elaboration, with data from www.idx.co.id (2018).

Table 1 explains the percentage of nonfinancial companies that did not hedge from 2010 - 2014 has increased from $79.59 \%$ to $81.30 \%$, compared to financial sector companies that actually showed a decline. The number of non-hedging financial firms from 2010 to 2014 tends to decline from $60 \%$ in 2010 to $51.25 \%$ in 2014 . This decrease indicates that financial firms tend to be more active in hedging policies over the past five years. Meanwhile, there is a tendency for nonfinancial companies not to conduct hedging policies within the last five years.

The underlying phenomenon of this is very interesting to discuss seeing that there was fluctuation of currency exchange rates and the increasing amount of foreign debt experienced by nonfinancial sector companies. This study aims to examine what internal factors affect the hedging policy by using derivative instruments conducted by nonfinancial sector companies. The previous research on hedging derivatives, revealing the reasons for not including the financial sector firms in their research. It was to be said that the financial sector companies acting as derivative users and as market-makers or providers in foreign exchange derivative transactions (Allayannis \& Ofek, 2001). Therefore, the support and motivation of financial companies in using derivatives can be very different from non-financial companies (Sprcic \& Sevic, 2012; Triki, 2005).

\section{Literature Review}

\subsection{The Internal Corporate Factors that Affect Hedging Policy: Empirical Evidence}

Hedging using derivative instruments is similar to buying insurance. The instrument provides protection against unexpected things in business, but sometimes the policy is used for speculative purposes in the market. The principle of hedging is to cover the loss of the initial asset position with the advantage of the position of the hedging instrument (Hague, 2004; Stulz, 2013). The previous research has identified the internal factors (liquidity, managerial ownership, dividend policy, leverage, cash flow volatility, and growth opportunity) of firms that affected hedging policies using instrument derivatives (Allayannis \& Ofek, 2001; Ameer, 2010; Clark \& Judge, 
2005; Haushalter, 2000; Nance, Smith, \& Smithson, 1993; Nguyen \& Faff, 2002; Sprcic \& Sevic, 2012), but the results are still ambiguous.

One of the internal variables that influence the hedging policy is liquidity. The liquidity variable proved to have a significant positive effect on hedging policy with instrument derivative (Clark \& Judge, 2005; Nance et al., 1993), while the finding was the significant negative effect (Nguyen \& Faff, 2002).

Another internal variable is managerial ownership. Ameer (2010) and Afza and Alam (2011) proved that managerial ownership has a significant positive effect on hedging policy. When managerial ownership increases, managers tend to minimize the risks that may be received so as to increase the value of the company through the use of derivative instruments. However, there is also evidence that managerial ownership is not significantly related to hedging policies (Géczy, Minton, \& Schrand, 1997; Haushalter, 2000).

The company's dividend policy has also been linked to hedging, and proved to have a positive effect (Afza \& Alam, 2011; Bartram, Brown, \& Fehle, 2009). While the effect is negatively due to the higher dividend payout ratio of a company, so it caused the lower of the need to hedge for companies which do not lack of funds (Haushalter, 2000; Sprcic \& Sevic, 2012). Leverage also becomes one of the determinants of the company in determining the implementation of hedging policy with derivative instruments. The significant positive effects on hedging policies are apparent when firms with foreign currency debts can experience losses from exchange rate fluctuations, so that hedging policies are undertaken to minimize such losses (Haushalter, 2000). The difference in results is shown by (Allayannis \& Ofek, 2001) and (Ameer, 2010) which showed the opposite results. The inconsistency of the results is also encountered in the effect of cash flow volatility on hedging policy. Marek-Klimczak (2008) found that cash flow volatility variables negatively affect hedging policy, where this is contrary to what Ameer (2010) has found.

The influence of growth opportunity on hedging policy has also been studied previously. It was found that there was a significant positive influence between growth opportunity and hedging policy (Haushalter, Klasa, \& Maxwell, 2007), or negative influence (Ameer, 2010; Shin \& Stulz, 2000).

\subsection{The Internal Corporate Factors and the Hedging Policies}

The relationship between the company's internal factors and the company's hedging policy has been explored a lot. The following explanation will elaborate more in the relationship of each factor with hedging through the use of derivative instruments.

Liquidity: Mello and Parsons (2000) examined the liquidity issues related to different hedging strategies that can affect a firm value. The purpose of hedging is to increase the company's financial flexibility. This can reduce the risk of costly 
financial difficulties, the effective cost of external financial constraints, and maximizes the value of investments. Firms that do not have financial constraints do not benefit from hedging, and the higher the company's financial constraint the greater the potential value of the hedge. The value of hedging depends heavily on the design of its strategies. The optimal hedging can minimize the variability in the marginal value of the firm's cash balances (Mello \& Parsons, 2000). In addition, companies can lower the probability of financial difficulty by having more liquid assets, ensuring that funds will be available to pay debt claims (Ameer, 2010). Then, firms with high levels of liquidity will be less likely to seek external funding in their corporate investment plans, as companies already have sufficient funds to their own investment programs (Nguyen \& Faff, 2002). Companies with a high level of liquidity will be less likely to experience problems in settling their short-term liabilities, and vice versa. The more liquid the company then the tendency to apply the hedging policy will be smaller as well.

\section{Hypothesis 1: Liquidity negatively affects the corporate hedging policy.}

Managerial ownership: When the managers act as shareholders, they tend to increase the supervision of the policies undertaken by these companies to reduce risk exposure. That means the greater the proportion of asset ownership of managers, the more intense the money hedging policy is done. Managers who invest their wealth in the corporation will be motivated more to reduce the risk of the company compared to an unaffiliated and diversified shareholder (Smith \& Stulz, 1985). Similarly, corporate managers who invest some of their own in-company wealth will seek to protect themselves from the risks that arise because their wealth becomes more sensitive to the firm's market value (Knopf, Nam, \& Thornton, 2002; Spanò, 2007). Managers trying to minimize the impact of risks that could affect the rate of return on shares they have in the company. In addition, there are advantages of hedging that is able to minimize the uncertainty that could affect the value of the company. Thus, a high level of managerial ownership will increase the possibility of hedging policy.

Hypothesis 2: Managerial Ownership positively affects the company's hedging policy.

Dividend Policy: Nguyen and Faff (2002) argued that the availability of funds from the company's net income can be a substitution of hedging, meaning that the company is able to manage the risks faced by using other techniques. But the availability of funds from the company can not be a substitute of the hedging when its availability is less. The reducing availability of the fund is because the company decided to pay dividends to shareholders. Companies with high dividend payout ratios will use more hedging derivative policies because of the reduced availability of their funds to pay dividends to shareholders and to reduce financial constraints (Berkman \& Bradbury, 1996; Reynolds \& Boyle, 2005). 
Hypothesis 3: Dividend payout ratio positively affects the company's hedging policy.

Leverage: A large debt level can cause the company to face its liquidity problem in paying for operational or investment costs (Bartram et al., 2009; Haushalter, 2000), so it is necessary to reduce the company's inadequate liquidity or financial distress. The greater the risk of corporate default, it will lead to new problems such as increased capital costs, bankruptcy costs, agency costs and the creation of information asymmetry. Hedging action in the face of transaction exposure will increase in line with increasing leverage levels (Nguyen \& Faff, 2002; Reynolds \& Boyle, 2005). Companies that have transactional exposure will have debt denominated in foreign currencies and therefore they also have a risk of exchange rate fluctuations.

Hypothesis 4: Leverage positively affects the company's hedging policy.

Cash Flow Volatility: Volatile cash flow indicates the uncertainty over highly business revenues, thus it potentially causes financial risks. Companies that have high cash flow volatility have a greater incentive to benefit from hedging policies with derivative instruments (Ameer, 2010). This volatility is influenced by changes in exchange rates as well as by the operations of the company (exports and imports) (Bartram, 2008; Froot, Scharfstein, \& Stein, 1993).

Hypothesis 5: Cash flow volatility positively affects the company's hedging policy.

Growth Opportunity: Companies with high growth rates need more funds in the future, especially external funds (one of them is debt) to meet the growth of investment (Laksana et al., 2017). However, debt carries a new risk for the company, as well as fluctuations in foreign exchange rates, inflation and interest rate increases. The increased risk exposure will encourage more on the intense hedging activities (Sprcic \& Sevic, 2012). Allayannis and Ofek (2001) argued that firms with greater growth opportunities will face higher investment costs (fluctuations in interest rates, commodity prices, and exchange rates), thus it will be more motivated to implement hedging policies. An expensive external financing problem is a classic problem under the investment, in which shareholders decide to reject low-risk projects if they value that the economic benefits will turn to creditors (Froot et al., 1993). Along with the rising risks faced by firms due to the impact of growth rates companies, then the probability of policy hedging will increase as well.

Hypothesis 6: Growth opportunity has a positive effect on the company's hedging policy.

Control Variables: This research incorporates the firm size variable as a variable control. The size of the company can be shown from total assets ownership, total sales, average total sales and average total assets (Haleblian \& Finkelstein, 1993; Judge, 2015; Ramlall, 2009). As the company grows, its activities are also 
increasingly complex, along with the level of risk facing the company. The large companies have a better control over market conditions and have more resources than small firms, so that companies are able to face economic competition and tend not to be vulnerable to economic fluctuations (Perrow, 1993). Reynolds and Boyle (2005) said that having the principle of economies of scale, large companies will tend to hedge more often due to the large scale of business transactions. Furthermore, large companies or multinational corporations will also be hedging more due to the more complex operational activities and exposure to changes in foreign currency exchange rates than the small firms.

\section{Methodology and Data}

\subsection{Model Specification and Methodology}

To test the determinant of hedging policy using instrument derivative, logistic regression analysis technique will be assisted by the SPSS version 23 program. Logistic regression has a dependent variable in the form of dummy variables ( 0 and 1 ), and does not require classical and normality assumption such as multiple linear regression analysis, while screening data outliers can still be done. In general, the logistic regression model equation is expressed as follows (Hair, Black, Babin, \& Anderson, 2010):

$$
p=\frac{1}{1+e^{(b 0+b 1 x 1+b 2 x 2+\ldots .+b n x n)}}
$$

$$
\operatorname{Ln} \frac{P}{1-p}=b_{0+} b_{1} x_{l}+b_{2} x_{2}+\ldots .+b_{n} x_{n}
$$

Where: $\mathrm{P}$ is the probability of the dependent variable; e is a natural logarithm; 0 represents regression control; b1, b2, ...., bn is the regression coefficient; and $\mathrm{x} 1, \mathrm{x} 1$, ..., $\mathrm{xn}$ as independent variables.

An analysis of logistic regression model testing (Gujarati \& Porter, 2003) begins with assessing the overall fit model on data. The statistics used are based on the likelihood function. The likelihood $\mathrm{L}$ of the model is the probability that the hypothesized model represents the input data. To test the null and alternative hypothesis, L is transformed to -2LogL. Statistics $-2 \operatorname{LogL}$ is sometimes called likelihood ratio $\chi^{2}$ statistic, where $\chi^{2}$ distribution with degree of freedom $\mathrm{n}-\mathrm{q}, \mathrm{q}$ is the number of parameters in the model. Hosmer and Lemeshow's Goodness of Fit Test are used to test the null hypothesis where the empirical datafits with the model. If the statistical value of Hosmer and Lemeshow's Goodness of Fit test is greater than 0.05 , then the null hypothesis is rejected which means there is a significant 
difference between the model and the observed value, or the model can not predict the observed value, and vice versa.

The next step it will be prepared the $2 \times 2$ Classification Table to calculate the correct and incorrect estimation value. The columns represent two predictive values of the dependent variable and this is susceptible (1) and not vulnerable (0), whereas the line indicates the actual observation value of the dependent variable (1) and not susceptible (0). In the perfect model, all cases will be on the diagonal with $100 \%$ accuracy forecasting. If the logistic regression model has homoscedasticity, then the correct percentage will be the same for both rows.

\subsection{Data}

The data used in this study is the annual data during the period 2010-2014, where it was obtained from the website of www.idx.co.id, Indonesia Capital Market Directory (ICMD), and Laboratory of Bloomberg. There are three kinds of variables; dependent variable, independent variable, and control variable. The dependent variable is hedging policy by using derivative instrument; represented by the dummy variable "1" if the company hedges with derivative instruments and " 0 " if the company does not hedge by using derivative instruments. The "dummy" variable is used to determine the probability level of hedging policy decision making in nonfinancial companies. The independent variables in this research are Liquidity ratio (LQ), Managerial Ownership (MO), Dividend Payout Ratio (DPR), Leverage (LEV), Cash Flow Volatility (CFV), and Growth Opportunity (GO); and the control variable in the form of Size. The proxies of each of these variables are presented in the following table.

Table 2. Variables and measurement

\begin{tabular}{|c|c|c|c|}
\hline NO. & VARIABLE & MEASUREMENT & REFERENCE \\
\hline 1. & Hedging Policy & $\begin{array}{l}\text { Doing hedging }=" 1 " \\
\text { No doing hedging= " } 0 "\end{array}$ & \\
\hline 2. & Liquidity (LIQ) & $\begin{array}{l}\text { Current Ratio }=\text { Current Assets/Current } \\
\text { Liabilities }\end{array}$ & $\begin{array}{l}\text { Nguyen and } \\
\text { Faff (2002) }\end{array}$ \\
\hline 3. & $\begin{array}{l}\text { Managerial } \\
\text { Ownership }\end{array}$ & $\begin{array}{l}\text { Managerial Ownership }=((\text { the number of } \\
\text { shares owned by directors }) /(\text { Outstanding } \\
\text { shares))X } 100 \%\end{array}$ & $\begin{array}{l}\text { Nguyen and } \\
\text { Faff (2002); } \\
\text { Reynolds and } \\
\text { Boyle (2005) }\end{array}$ \\
\hline 4. & $\begin{array}{l}\text { Dividen Policy } \\
\text { (DPR) }\end{array}$ & $\begin{array}{l}\text { Dividend Payout Ratio }=\text { Dividend per } \\
\text { share/Earning per share }\end{array}$ & $\begin{array}{l}\text { Reynolds and } \\
\text { Boyle (2005); } \\
\text { Afza and } \\
\text { Alam (2011) }\end{array}$ \\
\hline 5. & Leverage & Debt Equity Ratio = Total debt/Total equity & $\begin{array}{l}\text { Allayannis } \\
\text { and Ofek }\end{array}$ \\
\hline
\end{tabular}




\begin{tabular}{|c|c|c|c|}
\hline & & & $\begin{array}{lr}(2001) ; & \text { Afza } \\
\text { and } & \text { Alam } \\
(2011) & \\
\end{array}$ \\
\hline 6. & $\begin{array}{ll}\text { Cash } & \text { Flow } \\
\text { Volatility } & \\
(\mathrm{CFV}) & \end{array}$ & $\begin{array}{l}\text { Cash flow Volatility = Standard deviation } \\
(\sigma) \text { from net cash inflow operation for } 3 \\
\text { years before observation year. }\end{array}$ & Ameer (2010) \\
\hline 7. & $\begin{array}{l}\text { Growth } \\
\text { Opportunity } \\
(\mathrm{GO})\end{array}$ & $\begin{array}{l}\text { MVE/BVE }=\quad \text { (Outstanding } \\
\text { closingprice)/total equity }\end{array}$ & Ameer (2010) \\
\hline 8. & $\begin{array}{l}\text { Firm size } \\
(\mathrm{SIZE})\end{array}$ & Firm Size $=$ Ln (Total Assets) & \begin{tabular}{lr}
\multicolumn{2}{l}{ Allayannis } \\
and & Ofek \\
$(2001) ;$ & Afza \\
and & Alam \\
$(2011)$ & \\
\end{tabular} \\
\hline
\end{tabular}

There are 27 non-financial sector companies listed on the Indonesia Stock Exchange data in 2014-2016 which become the samples of this research. The sample is selected by using purposive sampling with the criteria: the company has a complete information in the audited and adequate annual financial statements; the company has assets and derivative debt in the balance sheet report for hedging purposes. While natural hedging and non-formal hedging strategies other than derivative instruments are not included in hedging decisions; the company has exposure to foreign currency transactions in its financial statements.

\section{Analysis of Results}

During the study period, obtained data as much as $27 \times 3=81$ data. In accordance with the objectives of the study, the overall observation will be seen firstly to the condition of the use of derivative instruments in implementing the hedging policy. Out of 81 from the observation data, 27 samples (34.6\%) have conducted hedging policy in protecting their financial risk. The remaining 53 samples $(65.4 \%)$ did not conduct hedging policy with derivative instrument as an alternative choice in protecting their company's financial risk.

Table 3. Hedging using derivative instruments, 2014-2016

\begin{tabular}{lcc}
\hline \multicolumn{1}{c}{ Method } & $\begin{array}{c}\text { Total } \\
\text { Sample }\end{array}$ & Percentage \\
\hline Not doing derivative hedging & 53 & $65.4 \%$ \\
\hline Doing derivative hedging & 28 & $34.6 \%$ \\
\hline Total & 81 & $100 \%$ \\
\hline
\end{tabular}

Source: Own elaboration, with data from www.idx.co.id (2018). 
To obtain an overview of the data for this research, the following centered dimensions are presented in Table 4.

Table 4. Descriptive statistics

\begin{tabular}{ccccc}
\hline Variabel & Min & Max & Mean & Std. Dev \\
\hline LIQ & 0.39 & 9.72 & 2.18 & 1.52 \\
MO & 0.00 & 15.94 & 2.59 & 4.28 \\
DPR & 0.20 & 85 & 36.74 & 18.70 \\
DER & .15 & 3.56 & 0.99 & 0.78 \\
CFV & 7.52 & 15.71 & 12.15 & 1.81 \\
GO & 0.14 & 6.94 & 2.68 & 1.60 \\
SIZE & 25.69 & 33.1 & 29.52 & 1.79 \\
N & 81 & & &
\end{tabular}

Source: Own elaboration, with data from www.idx.co.id (2018).

The overall sample shows an average liquidity of $2.18 \mathrm{x}$, meaning that the average sample has a current asset amount of $218 \%$ compared with current liabilities, with the distribution of 1.52. The highest level of liquidity is at PT. Media Nusantara Citra Tbk in 2014 amounted to 9.72x while the smallest level of liquidity obtained by PT Metropolitan Kentjana Tbk in 2013 amounted to 0.39x. The average managerial ownership is 2.59 or $2.58 \%$, the standard deviation of this variable is greater than the average of 4.28 which indicates that the data of this variable is more dispersed. The largest level of managerial ownership is obtained by PT Adaro Energy Tbk in 2012 (15.94\%) while the smallest level of managerial ownership obtained by PT Kimia Farma (Persero) Tbk in 2013-2014 (0.0023\%).

Meanwhile, the average dividend payout ratio (DPR) is $36.74 \%$ with a standard deviation value smaller than the average that is equal to 18.73. The largest level of DPR is owned by PT Indo Tambangraya Megah, Tbk in 2013 (85\%), while the lowest is owned by PT Kimia Farma (Persero) in 2014 (0.20\%).

Table 4 shows that the average Debt Equity Ratio (DER) is 0.99x, with a standard deviation of leverage that is lower than the average of 0.78 . The largest leverage rate is at PT XL Axiata Tbk in 2013 (3.56x), while the lowest obtained by PT Mandom Indonesia Tbk in $2012(0.15 x)$. The calculation of the standard deviation of the company's cash flow flows from 2014-2016 is obtained by 1.81. A lower value than the average (12.14) indicates that the volatility of cash flows is evenly distributed. The maximum value obtained by PT Astra International, Tbk in 2013 (15.71), while the minimum value obtained by PT. Pool Advista Indonesia, Tbk in 2012 (7.52). The growth opportunity proxies using MVE / BVE (market value equity / book value equity) ratio shows the average of $2.68 \mathrm{x}$, meaning that this figure is bigger than the standard deviation (1.60). The highest profit opportunity is obtained by PT Indofood, Tbk in 2013 (6.94x), while the lowest is PT Samudra Indonesia Tbk in 
$2013(0.14 x)$. Furthermore, the average Ln total assets is 29.52 where the lowest value of PT Pool Advista Indonesia, Tbk in 2012 (IDR 143,65 Billion) and the maximum value is PT Astra International, Tbk in 2014 (IDR 236,029 Billion).

\subsection{Model Feasibility Test}

The initial stage in logistic regression analysis is to assess the overall fit model of the data to determine whether the model fit with the data or not. Based on the test, it is expected that $\mathrm{H} 0$ should not be rejected for the fit model with the data. To test the hypothesis, it is necessary to analyze the -2 Log Likelihood on the first block (Block 0: Beginning Block) and second block (Block 1: Method = Enter). In addition to analysis of Log-Likelihood (-2LL) values, an analysis of Hosmer and Lemeshow's Test can also be performed to assess the fit model. If the value of Hosmer Lameshow's Goodness of Fit Test $\leq 0.05$, then the null hypothesis is rejected, meaning there is no difference between data estimation logistic regression model with observation data. The model fit test can be seen in Table 5.

Table 5. Model fit test

\begin{tabular}{|c|c|c|c|}
\hline Model Fit Test & Model Fit & Result of Model 1 & Result of Model 2 \\
\hline -2 Log Likelihood & $\begin{array}{l}\text {-2LLBlock } \\
\text { Number:0 } \\
\text {-2LLBlock } \\
\text { Number:1 }\end{array}$ & 104,446 & $\begin{array}{c}104,446 \\
61,131\end{array}$ \\
\hline Cox \&Snell R Square & $\begin{array}{l}\text { Cox \&Snell R } \\
\text { Square }\end{array}$ & 0,416 & 0,414 \\
\hline Nagelkerke R Square & $\begin{array}{ll}\text { Nagelkerke } & R \\
\text { Square } & \\
\end{array}$ & 0,575 & 0,572 \\
\hline \multirow[t]{2}{*}{$\begin{array}{l}\text { Hosmer and Lemeshow's } \\
\text { Test }\end{array}$} & Chi Square & 10,091 & 9,886 \\
\hline & p-value & 0,259 & 0,273 \\
\hline
\end{tabular}

Source: Own elaboration, with data from www.idx.co.id (2018).

Model 1 shows a statistical value of -2 LL 104,446 without entering the variable, it is only constant, but after the variable is inserted, the value of -2 LL decreases to 60,842 . Model 2 shows a statistical value of -2 LL of 104,446 (inserting constants only), but after entering the variable the $2 \mathrm{LL}$ value drops to 61,131 . The value of Cox \& Snell R Square in model 1 is 0,416 and the value of Nagelkerke R Square is 0,575 ; in model 2 the values are 0,414 and 0,572 , respectively.

So when the control variable is included in the test in order to increase the explainability of the independent variabl to the behavior of the dependent variable (hedging), then model 1 is rated better than model 2. Table 5 also shows the output of model 1 Hosmer and Lemeshow's Goodnessof Fit Test of 10,091. The significant 
value of both models is more than 0.05 , so it is concluded that models 1 and 2 are acceptable.

\subsection{Table of Classification}

The classification table for the two models is structured to measure the extent of the model's accuracy to predict the conditions.

Table 6. Classification of model 1 and 2

\begin{tabular}{|c|c|c|c|c|c|c|c|}
\hline \multicolumn{2}{|c|}{ Observed } & \multicolumn{3}{|c|}{ Model 1} & \multicolumn{3}{|c|}{ Model 2} \\
\hline \multirow{4}{*}{ Hedging } & \multirow[b]{3}{*}{0} & \multicolumn{2}{|c|}{$\begin{array}{c}\text { Predicted } \\
\text { Hedging } \\
\end{array}$} & \multirow[t]{2}{*}{$\begin{array}{c}\% \\
\text { Correct }\end{array}$} & \multicolumn{2}{|c|}{$\begin{array}{c}\text { Predicted } \\
\text { Hedging }\end{array}$} & \multirow[t]{2}{*}{$\begin{array}{c}\% \\
\text { Correct }\end{array}$} \\
\hline & & 0 & 1 & & 0 & 1 & \\
\hline & & 45 & 8 & 84.9 & 45 & 8 & 84.9 \\
\hline & 1 & 9 & 19 & 67.9 & 11 & 17 & 60.7 \\
\hline Overal \% & & & & 79.0 & & & 76.5 \\
\hline \multicolumn{8}{|c|}{$\begin{array}{l}\text { a. Constant is included in the model } \\
\text { b. The cut value is . } 500 \\
\text { Source: Own elaboration, with data from www.idx.co.id (2018). }\end{array}$} \\
\hline
\end{tabular}

\subsection{Hyphothetical Test}

Table 7 compares the models 1 and 2 in view of its effect on the dependent variable as follows.

Table 7. The test result of logistic regression on both models

\begin{tabular}{lcccccc}
\hline \multirow{2}{*}{ Variable } & \multicolumn{5}{c}{ Model 1 } & \multicolumn{3}{c}{ Model 2 } \\
\cline { 2 - 7 } & B & Sig. & Exp & B & Sig. & Exp \\
\hline Constanta & -15.042 & 0.047 & .000 & -11.532 & 0.002 & .000 \\
\hline LIQ & -1.191 & 0.021 & .304 & -1.060 & 0.021 & .313 \\
\hline MO & -0.035 & 0.687 & .965 & -0.030 & 0.725 & .971 \\
\hline DPR & 0.028 & 0.154 & 1.028 & 0.027 & 0.159 & 1.027 \\
\hline DER & -0.363 & 0.438 & .696 & -0.425 & 0.352 & .654 \\
\hline CFV & 0.975 & 0.005 & 2.650 & 1.087 & 0.000 & 2.965 \\
\hline GO & -0.404 & 0.061 & .667 & -0.406 & 0.058 & .666 \\
\hline
\end{tabular}




\begin{tabular}{lllllll}
\hline SIZE & 0.164 & 0.584 & 1.178 & - & - & - \\
\hline
\end{tabular}

Source: Own elaboration, with data from www.idx.co.id (2018).

In model 1, when control variables are included in the model, it is known that LIQ and $\mathrm{CFV}$ have an effect on hedging policies with hypothesized directions. And in model 2, when the control variables are removed from the model, it is also found the same result as in model 1 . The second model shows that the existence of the control variable (SIZE) has not been able to improve the prediction of the independent variables to match the hypothesis built.

However, EXP or Odds Ratio (OR) on each independent variable when the control variable is included or excluded from the model. The value of EXP shows the magnitude of the influence of a variable on its dependent variable. For example, the EXP of LIQ variables is 0.304 in model 1 and 0.313 in model 2. Companies with high liquidity tend to engage in hedging policies of $30.4 \%$ greater than firms with low liquidity (Model 1) and 31.3\% larger than firms with low liquidity (Model 2).

Referring to Table 7, we can formulate the logistic regression models (Models 1 and 2) as follows:

$$
\begin{aligned}
& \begin{aligned}
\operatorname{Ln} \frac{p}{1-p}= & -15.042-1.191 \mathrm{LIQ}-0.035 \mathrm{MO}+0.028 \mathrm{DPR}-0.363 \mathrm{DER}+ \\
& 0.758 \mathrm{CFV}-0.404 \mathrm{GO}+0.164 \mathrm{SIZE}
\end{aligned} \\
& \begin{aligned}
& \mathrm{Ln} \frac{p}{1-p}=-11.532-1.160 \mathrm{LIQ}-0.030 \mathrm{MO}+0.027 \mathrm{DPR}-0.425 \mathrm{DER}+ \\
& 1.087 \mathrm{CFV}-0.406 \mathrm{GO}
\end{aligned}
\end{aligned}
$$

Hypothesis 1 states that the LIQ variable has a negative effect on the probability of hedging policy received. From the regression result, it can be explained that the relationship between the odds of the company with the probability of using hedging is if other independent variables are considered fixed, then the decrease of each unit of variable Liquidity will cause the probability with factor used 0.313 on model 1 and 0.304 in model 2.

Hypothesis 2 states that managerial ownership (MO) has a positive effect on the probability of hedging policy which is rejected. Managerial ownership has a negative and insignificant influence on hedging policy with derivative instruments.

Hypothesis 3 refers to DPR variable with a coefficient 0.028 (significance level 0.154 ) in model 1 and 0.027 (significance level 0.159 ) in model 2, meaning that the dividend policy has no significant effect to company hedging policy. 
Hypothesis 4 states that leverage has positive effect on hedging policy with derivative instrument which is rejected, because the coefficient of DER in model 1 and 2 is not significant.

Hypothesis 5 refers to CFO where in model 1 has a coefficient of 0.975 and in model 2 of 1.087 while both coefficients are significant. It is concluded that the CFO variable has a positive and significant effect on the probability of hedging policy.

Hypothesis 6 refers to GO with a positive effect on hedging policy with derivative instruments which is rejected, because the GO coefficient shows the opposite direction that is hypothesized and not significant.

Thus, this study uses firm size as a control variable, and has a coefficient of 0.164 (significance level 0.584). Thus, FIFA has no significant effect on the probability of hedging policy on nonfinancial companies. The results show that whether or not the control variables in the model turn out to show consistent test results.

\section{Conclusions}

Based on the results of hypothesis analysis and testing, it can be concluded that:

a) Companies with high liquidity tend to lower the probability of conducting derivative policies.

b) Companies with shareholders in managerial positions have dividend policy, high leverage level and growth opportunity do not affect their probability to do derivative policy dealing.

c) Companies with high operating cash flow volatility will increase the probability for derivative hedging policies.

d) Results prove that firms with larger sizes do not find the probability of hedging policies compared to smaller companies.

A research that has been done by the authors is only to test the internal factors of the company alone regardless of the external factors suspected to affect hedging derivative activity. Therefore, a future research can consider the foreign sales variables (Allayannis \& Ofek, 2001) as well as tax (Singh \& Upneja, 2007) in order to obtain more comprehensive findings on hedging policies using derivative instruments.

\section{References:}

Afza, T. \& Alam, A. 2011. Determinants of corporate hedging policies: A case of foreign exchange and interest rate derivative usage. African Journal of Business Management, 5(14).

Aggarwal, R. 1991. Management of accounting exposure to currency changes: Role and evidence of agency costs. Managerial Finance, 17(4), 10-22. 
Allayannis, G., Lel, U. \& Miller, D.P. 2012. The use of foreign currency derivatives, corporate governance, and firm value around the world. Journal of International Economics, 87(1), 65-79.

Allayannis, G. \& Ofek, E. 2001. Exchange rate exposure, hedging, and the use of foreign currency derivatives. Journal of International Money and Finance, 20(2), 273-296.

Ameer, R. 2010. Determinants of corporate hedging practices in Malaysia. Malaysia.

Avellaneda, M., Levy, A. \& Parás, A. 1995. Pricing and hedging derivative securities in markets with uncertain volatilities. Applied Mathematical Finance, 2(2), 73-88.

Bartram, S.M. 2008. What lies beneath: Foreign exchange rate exposure, hedging and cash flows. Journal of Banking \& Finance, 32(8), 1508-1521.

Bartram, S.M., Brown, G.W. \& Fehle, F.R. 2009. International evidence on financial derivatives usage. Financial Management, 38(1), 185-206.

Berkman, H. \& Bradbury, M.E. 1996. Empirical evidence on the corporate use of derivatives. Financial Management, 5-13.

Clark, E. \& Judge, A. 2005. Motives for corporate hedging: evidence from the UK. Annals of Financial Economics, 1(01).

Cusatis, P. \& Thomas, M. 2005. Hedging Instruments and Risk Management: How to Use Derivatives to Control Financial Risk in any Market. McGraw Hill Professional.

Eun, C.S. \& Resnick, B.G. 1988. Exchange rate uncertainty, forward contracts, and international portfolio selection. The Journal of Finance, 43(1), 197-215.

Feiger, G. \& Jacquillat, B. 1979. Currency option bonds, puts and calls on spot exchange and the hedging of contingent foreign earnings. The Journal of Finance, 34(5), 11291139.

Figlewski, S. 1984. Hedging performance and basis risk in stock index futures. The Journal of Finance, 39(3), 657-669.

Froot, K.A., Scharfstein, D.S. \& Stein, J.C. 1993. Risk management: Coordinating corporate investment and financing policies. The Journal of Finance, 48(5), 1629-1658.

Garman, M.B. \& Kohlhagen, S.W. 1983. Foreign currency option values. Journal of International Money and Finance, 2(3), 231-237.

Géczy, C., Minton, B.A. \& Schrand, C. 1997. Why firms use currency derivatives. The Journal of Finance, 52(4), 1323-1354.

Georgiev, G. 2001. Benefits of commodity investment. The Journal of Alternative Investments, 4(1), 40-48.

Glen, J. \& Jorion, P. 1993. Currency hedging for international portfolios. The Journal of Finance, 48(5), 1865-1886.

Gujarati, D.N. \& Porter, D.C. 2003. Basic Econometrics. 4th ed., New York: McGraw-Hill.

Hague, I.P. 2004. IAS 39: Underlying principles. Accounting in Europe, 1(1), 21-26.

Hair, J.F., Black, W.C., Babin, B.J. \& Anderson, R.E. 2010. Multivariate Data Analysis (A Global Perspective). Upper Saddle River, New Jersey, Pearson Education, Inc.

Haleblian, J. \& Finkelstein, S. 1993. Top management team size, CEO dominance, and firm performance: The moderating roles of environmental turbulence and discretion. Academy of Management journal, 36(4), 844-863.

Haushalter, D., Klasa, S. \& Maxwell, W.F. 2007. The influence of product market dynamics on a firm's cash holdings and hedging behavior. Journal of Financial Economics, 84(3), 797-825, doi:https://doi.org/10.1016/j.jfineco.2006.05.007

Haushalter, G.D. 2000. Financing policy, basis risk, and corporate hedging: Evidence from oil and gas producers. The Journal of Finance, 55(1), 107-152.

Hill, J. \& Schneeweis, T. 1981. A note on the hedging effectiveness of foreign currency futures. Journal of Futures Markets, 1(4), 659-664. 
Junkus, J.C. \& Lee, C.F. 1985. Use of three stock index futures in hedging decisions. Journal of Futures Markets, 5(2), 201-222.

Knopf, J.D., Nam, J. \& Thornton, J.H. 2002. The volatility and price sensitivities of managerial stock option portfolios and corporate hedging. The Journal of Finance, 57(2), 801-813.

Laksana, R.D. \& Hersugondo, H. 2016. Does economic value added influence the shareholder value in Indonesia? International Journal of Applied Business and Economic Research, 14(3), 1547-1560.

Laksana, R.D., Hersugondo, H., Wahyudi, S. \& Muharam, H. 2017. The New Decomposition Asset Growth Effect. An Empirical Evidence of Indonesia. Journal of Applied Economic Sciences, 12(4), 977-984.

Marek-Klimczak, K. 2008. Corporate hedging and risk management theory: evidence from Polish listed companies. The Journal of Risk Finance, 9(1), 20-39.

Martin, A.D. \& Mauer, L.J. 2003. Transaction versus economic exposure: which has greater cash flow consequences? International Review of Economics \& Finance, 12(4), 437-449.

Massa, M. \& Simonov, A. 2006. Hedging, familiarity and portfolio choice. The Review of Financial Studies, 19(2), 633-685.

Mello, A.S. \& Parsons, J.E. 2000. Hedging and liquidity. The Review of Financial Studies, 13(1), 127-153.

Merton, R.C. 1976. Option pricing when underlying stock returns are discontinuous. Journal of Financial Economics, 3(1-2), 125-144.

Nance, D.R., Smith, C.W. \& Smithson, C.W. 1993. On the determinants of corporate hedging. The Journal of Finance, 48(1), 267-284.

Nguyen, H. \& Faff, R. 2002. On the determinants of derivative usage by Australian companies. Australian Journal of Management, 27(1), 1-24.

Pantzalis, C., Simkins, B.J. \& Laux, P.A. 2001. Operational hedges and the foreign exchange exposure of US multinational corporations. Journal of International Business Studies, 32(4), 793-812.

Ramlall, I. 2009. Determinants of hedging: An empirical investigation for Mauritius. IUP Journal of Financial Risk Management, 6(3/4), 99.

Reynolds, M. \& Boyle, G. 2005. Derivative use and investment: An empirical analysis of New Zealand listed companies. Unpublished working paper, University of Otago, Dunedin, NZ and Victoria University of Wellington, Kelburn, NZ.

Schwartz, E.S. 1997. The stochastic behavior of commodity prices: Implications for valuation and hedging. The Journal of Finance, 52(3), 923-973.

Singh, A. \& Upneja, A. 2007. Extent of hedging in the US lodging industry. International Journal of Hospitality Management, 26(4), 764-776.

Smith, C.W. \& Stulz, R.M. 1985. The determinants of firms' hedging policies. Journal of Financial and Quantitative Analysis, 20(4), 391-405.

Spanò, M. 2007. Managerial ownership and corporate hedging. Journal of Business Finance \& Accounting, 34(7-8), 1245-1280.

Sprcic, D.M. \& Sevic, Z. 2012. Determinants of corporate hedging decision: Evidence from Croatian and Slovenian companies. Research in International Business and Finance, 26(1), 1-25.

Stulz, R. 2013. How companies can use hedging to create shareholder value. Journal of applied corporate finance, 25(4), 21-29. 